\title{
PHYTOCONSTITUENTS AND BIOLOGICAL EVALUATION OF JUSTICIA SPICIGERA CULTIVATED IN EGYPT BY
}

\author{
Ahmed Othman, Wael M. Afifi, Muhamad Abd-Elraouf, Lotfy D. Ismail
}

FROM

${ }^{1}$ Pharmacognosy Department, Faculty of Pharmacy, Al-Azhar University, Cairo, Egypt

\begin{abstract}
Four compounds were isolated from the aerial parts of Justicia spicigera Schltdl. (Acanthaceae) and were identified as uracil (1), uridine (2), megastigmane vomifoliol-9O- $\beta$-D-Glucopyranoside (3) and $\beta$-sitosterol (4). The structures of these compounds were characterized by spectroscopic methods (IR, ${ }^{1} \mathrm{H}-\mathrm{NMR}$, APT, 2D NMR and EI/MS). The different crude extracts showed selective inhibitory activity against Mycobacterium tuberculosis (TB), remarkable cytotoxic activities against Human breast cancer (MCF-7) cell lines and Human lung carcinoma (A-549) cell lines and weak antimicrobial activities. This is the first report concerning the isolation of compounds (1-3) from genus Justicia.
\end{abstract}

Key words: Justicia spicigera, phytoconstituents, Anti-TB and Cytotoxicity

\section{Introduction}

Acanthaceae is a large family comprising, 4300 species in 346 genera (Wasshausen \& Wood, 2004). Members of this family are found mostly in the tropics, but occur also in the temperate region, mainly in the Mediterranean (Mabberley \& David, 1993). Justicia is the largest genus of Acanthaceae, with approximately 600 species that are found in pantropical and tropical regions (Durkee, 1986). The species of Justicia are described as erect perennial herbs or subshrubs (Deng et al., 2016). Leaves present cystoliths and are petiolate with a leaf margin that is usually entire. Species of Justicia are widely used in folk medicine to treatment of respiratory, gastrointestinal, and heart diseases, some of them are used for treatment of tuberculosis, diabetes, cancer, inflammation, rheumatism, and arthritis, also exhibiting antimalarial, antibacterial, antiviral, anti-HIV, and anthelminthic properties (Correa \& Antonio, 2012; Gomez-Verjan et al.,2012). Compounds of different chemical classes have been isolated from Justicia species, such as coumarins, flavonoids, alkaloids, iridoids, diterpenes, and triterpenes. In addition, different lignan compounds are isolated from genus Justicia (Correa \& Antonio, 2012; Awan et al., 2014; Wen-Kun al., 2014). Justicia spicigera plant is a shrub that grows in Mexico and known as muicle. It is used as immunostimulatory (Alonso-Castro et al., 2012). In traditional medicine it is mainly used against dysentery either from microbes or parasites and has an effect on intestinal motility. Justicia spicigera contains various bioactive compounds such as carbohydrates, pectins, glycosides, pigments, essential oils and minerals. Phenolic compounds, flavonoids such as kaempferitrin, and kaempferol trirhamnoside have been isolated from leaves and flowers (Baqueiro-Pena et al., 2014). 


\section{Material and methods:}

\section{Experimental:}

General experimental procedures: EI/MS spectra were measured using El/MS 502 mass spectrometer having a direct inlet system and operating at $70 \mathrm{eV}$. IR spectra were carried out on a Nicolet 205 FT IR spectrometer connected to a Hewlett-Packard Color Pro. Plotte. NMR spectra were recorded on a Varian Mercury $400 \mathrm{MHz}$ spectrometer at $400\left({ }^{1} \mathrm{H}\right)$ and $100 \mathrm{MHz}$ (APT) in DMSO- $d, \mathrm{CDCl}_{3}$ and $\mathrm{CD}_{3} \mathrm{OD}$ solution and chemical shifts were expressed in $\delta(\mathrm{ppm})$ with reference to TMS and coupling constant $(J)$ in Hertz. Column chromatographic separation was performed on silica gel 60 (Si gel 60, Merck), sephadex LH-20 (Pharmacia) and C-18 Column (reversed SPE) (Phenomenex). TLC was performed on precoated TLC plates with silica gel 60 F254 $(0.2 \mathrm{~mm}$, Merck). Developed chromatograms were visualized by spraying with $1 \%$ vanillin- $\mathrm{H}_{2} \mathrm{SO}_{4}$, followed by heating at $100{ }^{0} \mathrm{C}$ for $5 \mathrm{~min}$.

\section{Plant material:}

Justicia spicigera aerial parts were collected in March 2015 from Giza Zoo garden and were kindly identified by staff members of Faculty of Science, Ain-shams University and Teriza Labib, Botanist of Orman Botanical Garden. A voucher herbarium specimen had been deposited in the Department of Pharmacognosy, Faculty of Pharmacy, Al-Azhar University, Nasr city, Cairo, Egypt.

\section{Extraction and isolation:}

The aerial parts of Justicia spicigera $(3 \mathrm{Kg})$ were air-dried, ground to fine powder and exhaustively extracted with $70 \%$ methanol three times to yield $330 \mathrm{~g}$ of a dark solid extract, which was then suspended in water $(500 \mathrm{ml})$ and successively partitioned with $n$-hexane, dichloromethane, ethyl acetate and $n$-butanol.

The $n$-butanol extract (30gm) was chromatographed on silica gel column (VLC) and eluted with dichloromethane-methanol (100:0-50:50) to obtain five fractions of A, B, C, D and E. Fraction B (1.13g) was rechromatographed on series of silica gel columns and eluted with dichloromethane-methanol (100:0-80:20 then 93:7-75-25) followed by final purification on Sephadex LH-20 columns eluting with $100 \% \mathrm{MeOH}$ to afford compound $1(20 \mathrm{mg})$. Fraction $\mathrm{C}(1.2 \mathrm{~g})$ was rechromatographed on silica gel column and eluted with dichloromethane-methanol (100:0-75-25) followed by final purification on Sephadex LH-20 column eluting with $100 \% \mathrm{MeOH}$ and C-18 column water-methanol (100:0-70:30) to afford compounds 2 (7mg) and compound 3 (10mg).

The ethyl acetate extract was chromatographed on silica gel column (VLC) and eluted with $n$-hexane-ethyl acetate gradient (100:0-50:50) to obtain four fractions of A, B, C, and D. Fraction A of ethyl acetate was further rechromatographed on silica gel column and eluted with $n$-hexane-ethyl acetate gradient (100:0-50:50) followed by final purification on sephadex LH-20 column eluting with $100 \% \mathrm{MeOH}$ to give compound 4 (16mg). 
Compound [1]: White amorphous powder; ${ }^{1} \mathrm{H}-\mathrm{NMR}$ (400 MHz, DMSO- $d_{6}$ ), $\delta 11$ (brs, NH-1), $5.4(1 \mathrm{H}, \mathrm{d}, \mathrm{J}=7.6 \mathrm{~Hz}, \mathrm{H}-5), 7.4(1 \mathrm{H}, \mathrm{d}, \mathrm{J}=7.6 \mathrm{~Hz}, \mathrm{H}-6)$; APT-NMR $(100 \mathrm{MHz}$, DMSO- $\left.d_{6}\right), \delta 164.35(\mathrm{C}-2), 151.52(\mathrm{C}-4), 100.23(\mathrm{C}-5), 142.20$ (C-6); EI /MS at m/z $112[\mathrm{M}]^{+}$(calc. for $\mathrm{C}_{4} \mathrm{H}_{4} \mathrm{~N}_{2} \mathrm{O}_{2}$ ), $113[\mathrm{M}+1]^{+}$.

Compound [2]: Yellowish brown amorphous powder; ${ }^{1} \mathrm{H}-\mathrm{NMR}$ (400 MHz, $\left.\mathrm{CD}_{3} \mathrm{OD}\right), \delta$ $5.7(1 \mathrm{H}, \mathrm{d}, \mathrm{J}=8 \mathrm{~Hz}, \mathrm{H}-5), 8.0(1 \mathrm{H}, \mathrm{d}, \mathrm{J}=8 \mathrm{~Hz}, \mathrm{H}-6), 5.9\left(1 \mathrm{H}, \mathrm{d}, \mathrm{J}=4.8 \mathrm{~Hz}, \mathrm{H}-1^{\prime}\right), 3.5$ $\left(1 \mathrm{H}, \mathrm{m}, \mathrm{H}-2^{\prime}\right), 4.0(1 \mathrm{H}, \mathrm{m}, \mathrm{H}-3$ '), 4.17 (1H, m, H-4'), 3.7 (1H , dd , J=12, 2.8Hz, H-5'a), $3.8\left(1 \mathrm{H}, \mathrm{dd}, \mathrm{J}=12,2.8 \mathrm{~Hz}, \mathrm{H}-5\right.$ 'b); APT-NMR (100 MHz, $\left.\mathrm{CH}_{3} \mathrm{OD}\right) \delta 166.22(\mathrm{C}-2)$, 152.48 (C-4), 102.71 (C-5), 142.71 (C-6), 90.65 (C-1'), 75.66 ( C-2'), 71.26 ( C-3'), $86.31\left(\mathrm{C}-4\right.$ '), $62.23\left(\mathrm{C}-5^{\prime}\right)$.; EI/MS at m/z $244[\mathrm{M}]^{+}$(calc. for $\mathrm{C}_{9} \mathrm{H}_{12} \mathrm{~N}_{2} \mathrm{O}_{6}, 245[\mathrm{M}+\mathrm{H}]^{+}$, and $140\left[\mathrm{C}_{5} \mathrm{H}_{4} \mathrm{~N}_{2} \mathrm{O}_{3}\right]^{+}$.

Compound [3]: Yellowish brown crystals, ${ }^{1} \mathrm{H}-\mathrm{NMR}$ (400 MHz, DMSO-d $d_{6}$ ), $\delta 2.02$ $(1 \mathrm{H}, \mathrm{d}, \mathrm{J}=17 \mathrm{~Hz}, \mathrm{H}-2 \mathrm{a}), 2.5(1 \mathrm{H}, \mathrm{d}, \mathrm{J}=17 \mathrm{~Hz}, \mathrm{H}-2 \mathrm{~b}), 5.76(1 \mathrm{H}, \mathrm{brs}, \mathrm{H}-4), 5.9(1 \mathrm{H}, \mathrm{d}, \mathrm{J}=$ $15.6 \mathrm{~Hz}, \mathrm{H}-7), 5.6(1 \mathrm{H}, \mathrm{dd}, \mathrm{J}=6,15.6 \mathrm{~Hz}, \mathrm{H}-8), 4.4(1 \mathrm{H}, \mathrm{m}, \mathrm{H}-9), 1.2(3 \mathrm{H}, \mathrm{d}, \mathrm{J}=604 \mathrm{~Hz}$, $\mathrm{H}-10), 0.93$ (3H, S, H-11), 0.91 ( $3 \mathrm{H}, \mathrm{S}, \mathrm{H}-12), 1.8$ (3H.S, H-13), glucose moiety; $\delta$ $4.01\left(1 \mathrm{H}, \mathrm{d}, \mathrm{J}=7.6 \mathrm{~Hz}, \mathrm{H}-1^{\prime}\right), 2.9$ (1H, m, H-2'), 3.5 (1H, m, H-3'), 3.02 (1H, m, H-4'), 3.8 (1H, m, H-5'), 3.7 (2H, m, H-6'); APT-NMR (100 MHz, DMSO-d 6 ) $\delta 49.82$ (C-1), 41.42 (C-2), 197-87 (C-3), 126.01 (C-4), 164.27 (C-5), 78.39 (C-6), 132.10 (C-7), 131.92 (C-8), 77.62 (C-9), 22.5 (C-10), 24.5 (C-11), 23.5 (C-12), 19.1 (C-13); glucose moiety; $\delta 100.4$ (C-1'), 72.5 (C-2'), 73.75 (C-3'), 70.5 (C-4'), 77.4 (C-5'), 61.5 (C-6'); EI-MS at m/z $386[\mathrm{M}]^{+}$(calc. for $\left.\mathrm{C}_{19} \mathrm{H}_{30} \mathrm{O}_{8}\right), 387[\mathrm{M}+\mathrm{H}]^{+}$, and $149\left[\mathrm{C}_{10} \mathrm{H}_{13} \mathrm{O}\right]^{+}$.

Compound [4]: White crystals, ${ }^{1} \mathrm{H}-\mathrm{NMR}\left(400 \mathrm{MHz}, \mathrm{DMSO}-d_{6}\right), 3.6(1 \mathrm{H}, \mathrm{m}, \mathrm{H}-3), 5.4$ (1H, m, H-6), 0.63 (3H, S, H-18), 0.95 (3H, S, H-19), 0.83 (3H,d, J=6.5Hz, H-21), 0.80 $(3 \mathrm{H}, \mathrm{d}, \mathrm{J}=6.5 \mathrm{~Hz}, \mathrm{H}-26), 0.87(3 \mathrm{H}, \mathrm{d}, \mathrm{J}=6.5 \mathrm{~Hz}, \mathrm{H}-27), 0.92(3 \mathrm{H}, \mathrm{t}, \mathrm{J}=7 \mathrm{~Hz}, \mathrm{H}-29)$; APTNMR (100 MHz, DMSO-d $d_{6} \delta 33.86$ (C-1), 31.79 (C-2), 71.95 (C-3), 39.92 (C-4), 140.91 (C-5), 121.86 (C-6), 31.6 (C-7), 31.79 (C-8), 50.28 (C-9), 36.65 (C-10), 21.22 (C-11), 37.40 (C-12), 42.43 (C-13), 56.91 (C-14), 23.21 (C-15), 28.39 (C-16), 56.20 (C17), 12.0 (C-18), 19.54 (C-19), 36.29 (C-20), 19.17 (C-21), 34.09 (C-22), 24.44 (C-23), 45.98 (C-24), 29.29 (C-25), 19.96 (C-26), 18.92 (C-27), 23.21 (C-28), 12.12 (C-29); $\mathrm{EI} / \mathrm{MS} \mathrm{m} / \mathrm{z} 414[\mathrm{M}]^{+}$(calc. for $\mathrm{C}_{29} \mathrm{H}_{50} \mathrm{O}$ ).

\section{Evaluation of antimicrobial activity}

\section{Agar well diffusion method:}

The antimicrobial activity of different extracts of Justicia spicigera aerial parts was tested against a range of micro-organisms including two Gram-positive bacteria, two Gram-negative bacteria and two fungal species using the agar well diffusion assay method (Hindler et al., 1994) and the results were shown in (Table 1). All extracts were tested in concentration $5 \mathrm{mg} / \mathrm{ml}$ and the inhibition zone was measure around each well after $24 \mathrm{~h}$.

\section{Evaluation of antituberculosis activity}

\section{Microplate Alamar Blue Assay:}

The antituberculosis activity of different crude extracts of Justicia spicigera was evaluated using the microplate alamar blue assay (Franzblau et al., 1998) which was performed in black, clear-bottomed, 96 well microplates. Outer perimeter wells were filled with sterile water to prevent dehydration in experimental wells. Extracts dilutions 
were prepared in dimethyl sulfoxide and subsequent two-fold dilutions were performed in microplates $0.1 \mathrm{ml}$ of $105 \mathrm{CFU} / \mathrm{ml}$ Mycobacterium tuberculosis inoculum was added to wells, additional control wells consisted of bacteria only as control. The different extracts and Isoniazide (standard drug) were tested at concentration of $100 \mu \mathrm{g}$. Starting at day 4 of incubation, $20 \mu \mathrm{l}$ of alamar blue solution and $12.5 \mu \mathrm{l}$ of $20 \%$ tween 80 were added to the entire plate. Plates were incubated at $37^{\circ} \mathrm{C}$, and results recorded at $24 \mathrm{~h}$ post reagent addition at $590 \mathrm{~nm}$. Percent inhibition was defined as (mean of test well $/$ mean of B wells) $\times 100$.

\section{Evaluation of cytotoxic activity:}

\section{Cell culture:}

Human breast cancer (MCF-7) and Human lung cancer (A-549) cell lines were obtained from the National Cancer Institute (Cairo, Egypt) and maintained in Roswell Park Memorial Institute medium (RPMI1640) supplemented with $100 \mathrm{mg} / \mathrm{ml}$ of streptomycin, 100 units $/ \mathrm{ml}$ of penicillin and $10 \%$ of heat-inactivated fetal bovine serum in a humidified $5 \%(\mathrm{v} / \mathrm{v}) \mathrm{CO} 2$ atmosphere at $37^{\circ} \mathrm{C}$.

\section{Cytotoxic assay:}

The cytotoxic activity of total extract, $n$-hexane, dichloromethane, ethyl acetate, $n$ - butanol and water extract of Justicia spicigera aerial parts (serial dilutions 0-500 $\mu \mathrm{g} / \mathrm{ml}$ ) were evaluated against Human breast cancer (MCF-7) and Human lung cancer (A-549) cell lines using viability assay (Mosmann \& Tim, 1983). After the end of the incubation period, media were aspirated and the crystal violet solution (1\%) was added to each well for at least 30 minutes. The stain was removed and the plates were rinsed using tap water until all excess stain is removed. Glacial acetic acid (30\%) was then added to all wells and mixed thoroughly, and then the absorbance of the plates were measured after gently shaken on microplate reader using a test wavelength of $490 \mathrm{~nm}$. Treated samples were compared with the cell control in the absence of the tested compounds. All experiments were carried out in triplicate. The cell cytotoxic effect of each tested extract was calculated. The optical density was measured with the microplate reader to determine the number of viable cells and the percentage of viability was calculated as [1- (ODt/ODc)]x100 where ODt is the mean optical density of wells treated with the tested sample and ODc is the mean optical density of untreated cells. The relation between surviving cells and drug concentration is plotted to get the survival curve of each tumor cell line after treatment with the specified compound. The $50 \%$ inhibitory concentration (IC50), the concentration required to cause toxic effects in 50\% of intact cells, was estimated from graphic plots of the dose response curve for each concentration using Graphpad Prism software.

\section{Results and discussion}

Dried aerial parts of Justicia spicigera were extracted with $70 \%$ methanol and then fractionated with $n$-hexane, dichloromethane, ethyl acetate and $n$-butanol. From these extracts and by using combined chromatographic separations, four compounds were isolated (Fig. 1). Their structures were elucidated using spectroscopic methods. The isolated compounds were identified as:

Uracil [1], $\mathrm{Rf}=0.8$, TLC solvent system (chloroform-methanol-water 80:20:2), obtained as white powder and showed a molecular ion peak at m/z $112[\mathrm{M}]+$ in EI/MS. 
In the ${ }^{1} \mathrm{H}-\mathrm{NMR}$ spectrum of compound 1, two doublets of typical olefinic proton signals at $\delta 7.4(\mathrm{~J}=7.6 \mathrm{~Hz})$ and $5.4(\mathrm{~J}=7.6 \mathrm{~Hz})$ were observed. In APT-NMR, C-6 \& C-5 were confirmed by presence of signals at $\delta_{\mathrm{C}} 142.20 \& 100.23 \mathrm{ppm}$ respectively. Accordingly, the structure of compound 1 was elucidated as uracil by comparison of the spectral data, as described in the literature (Huo et al., 2005).

Uridine [2], $\mathrm{R}_{\mathrm{f}}=0.31$, TLC solvent system (chloroform-methanol-water 80:20:2), obtained as yellowish brown powder and displayed a molecular ion peak at $\mathrm{m} / \mathrm{z} 244$ $[\mathrm{M}]+$ in EI/MS. In the ${ }^{1} \mathrm{H}-\mathrm{NMR}$ spectrum of compound 2, two doublets of typical olefinic proton signals at $\delta 8.0(\mathrm{~J}=8 \mathrm{~Hz})$ and $5.7(\mathrm{~J}=8 \mathrm{~Hz})$ were observed which also confirmed by presence of signals at $\delta_{\mathrm{C}} 142.71 \& 102.71 \mathrm{ppm}$ in APT-NMR. The presence of signal at $\delta_{\mathrm{H}} 5.9(1 \mathrm{H}, \mathrm{d}, \mathrm{J}=4.8 \mathrm{~Hz})$ assigned for anomeric proton at $\mathrm{C}-1$ ' which also confirmed by presence of signal at $\delta_{C} 90.65$ in APT-NMR spectrum. The ${ }^{1} \mathrm{H}$ and APT-NMR spectra were in close agreement with those of a previous report (Huo et al.,2005)。

Vomifoliol-9-O- $\beta$-D-Glucopyranoside [3], Rf = 0.6, TLC solvent System (chloroformmethanol 80:20), obtained as yellowish brown crystals and displayed a molecular ion peak at m/z $386[\mathrm{M}]+$. The ${ }^{1} \mathrm{H}-\mathrm{NMR}$ spectrum showed signal at $\delta_{\mathrm{H}} 5.76 \mathrm{ppm}(1 \mathrm{H}, \mathrm{S})$ indicates olefenic proton at C-4 which also confirmed by signal at $\delta_{\mathrm{c}} 126.01 \mathrm{ppm}$ in APT-NMR spectrum. Signal at $\delta_{\mathrm{H}} 5.9 \mathrm{ppm}(1 \mathrm{H}, \mathrm{d}, \mathrm{J}=15.6 \mathrm{~Hz})$ assigned for $\mathrm{H}-7$ and at $\delta_{\mathrm{H}} 5.6 \mathrm{ppm}(1 \mathrm{H}, \mathrm{dd}, \mathrm{J}=15.6 \& 6 \mathrm{~Hz})$ assigned for $\mathrm{H}-8$, which also confirmed by signals at $\delta_{\mathrm{c}} 132.1$ and $131.92 \mathrm{ppm}$ in APT spectrum assigned for C-7 and C-8 respectively. $\mathrm{H}-$ 9 was identified by presence of signal at $\delta_{\mathrm{H}} 4.4 \mathrm{ppm}(1 \mathrm{H}, \mathrm{m})$ which also confirmed by signal at $\delta_{\mathrm{c}} 77.62 \mathrm{ppm}$ assigned for $\mathrm{C}-9$, while the two diasteriotopic protons at $\mathrm{C}-2$ identified by signals $\delta_{\mathrm{H}} 2.02 \mathrm{ppm}(1 \mathrm{H}, \mathrm{d}, \mathrm{J}=17 \mathrm{~Hz}) \& 2.5 \mathrm{ppm}(1 \mathrm{H}, \mathrm{d}, \mathrm{J}=17 \mathrm{~Hz})$ assigned for $\mathrm{H}-2 \mathrm{a}$ and $\mathrm{H}-2 \mathrm{~b}$ and also confirmed by signal at $\delta_{\mathrm{c}} 41.42 \mathrm{ppm}$ while signals at $\delta_{\mathrm{c}}$ 197.87, 164.27 \& $78.39 \mathrm{ppm}$ assigned for quaternary carbons C-3, C-5, and C-6 respectively. Singlet peaks at $\delta_{\mathrm{H}} 0.93(3 \mathrm{H}, \mathrm{S}), 0.91(3 \mathrm{H}, \mathrm{S}), 1.8(3 \mathrm{H}, \mathrm{S})$ assigned for $\mathrm{H}-$ $11, \mathrm{H}-12$ and $\mathrm{H}-13$ respectively, which also confirmed by signals at $\delta_{\mathrm{c}} 24.5,23.5$ and $19.1 \mathrm{ppm}$ assigned for $\mathrm{C}-11, \mathrm{C}-12$ \& $\mathrm{C}-13$ in APT spectrum respectively, while the peak at $\delta_{\mathrm{H}} 1.2(3 \mathrm{H}, \mathrm{d}, \mathrm{J}=6.4 \mathrm{~Hz})$ assigned for $\mathrm{H}-10$ which also confirmed by signal at $\delta_{\mathrm{c}}$ $22.5 \mathrm{ppm}$. Glucose moiety was identified by the presence of signal at $\delta_{\mathrm{H}} 4.01 \mathrm{ppm}$ $(1 \mathrm{H}, \mathrm{d}, \mathrm{J}=7.6 \mathrm{~Hz})$ suggested an anomeric proton with $\beta$-configuration which also was confirmed by signal at $\delta_{\mathrm{c}} 100.4 \mathrm{ppm}$ assigned for C-1' (anomeric carbon). The compound 3 is suggested to be vomifoliol-9-O- $\beta$-D-Glucopyranoside by comparison it's spectral data with those in literature (Herderich et al., 1992).

$\boldsymbol{\beta}$-sitosterol [4], Rf = 0.5, TLC solvent systems ( $n$-hexane-ethyl acetate 80:20), obtained as white crystals and displayed a molecular ion peak at $\mathrm{m} / \mathrm{z} 414[\mathrm{M}]^{+}$. Signals in the ${ }^{1} \mathrm{H}-$ NMR spectrum were observed mainly in the upfield region. The spectra exhibited two signals with high chemical shifts values; the first one resonated in the olefinic region and the other one was observed a little up field region. The olefinic signal at $\delta 5.3(1 \mathrm{H}$, $\mathrm{m})$ appeared to be characteristic of the sterols, and it was assigned to H-6 proton in the $\beta$-sitosterol (4) chemical skeleton. The ${ }^{1} \mathrm{H}-\mathrm{NMR}$ spectra of compound 4 also exhibited a signal corresponding to the proton connected to C-3 hydroxyl group which appeared as a multiplet at $\delta 3.52(1 \mathrm{H}, \mathrm{m})$. The APT- NMR spectra exhibited 29 carbon signals, characteristic of phytosterols. Signals appeared at $\delta 33.86(\mathrm{C}-1), 31.79(\mathrm{C}-2), 71.95$ (C3), 39.92 (C-4), 140.91 (C-5), 121.86 (C-6), 31.6 (C-7), 31.79 (C-8), 50.28 (C-9), 36.65 
(C-10), 21.22 (C-11), 37.40 (C-12), 42.43 (C-13), 56.91 (C-14), 23.21 (C-15), 28.39 (C16), 56.20 (C-17), 12.0 (C-18), 19.54 (C-19), 36.29 (C-20), 19.17 (C-21 ), 34.09 (C-22), 24.44 (C-23), 45.98 (C-24), 29.29 (C-25), 19.96 (C-26), 18.92 (C-27), 23.21 (C-28), 12.12 (C-29). These data were in agreement with published literature for $\beta$-sitosterol and by comparison with authentic sample (Pierre and Moses, 2015; Patra et al. 2010).

To our best knowledge, compounds [1-3] suggested to be first reported in genus Justicia.<smiles>O=c1cc[nH]c(=O)[nH]1</smiles>

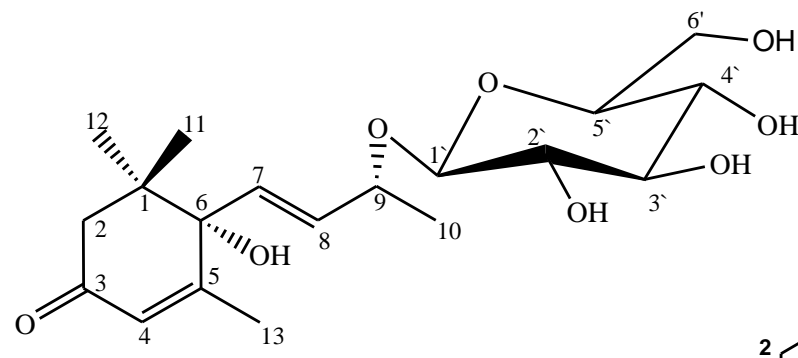

3<smiles>O=c1ccn([C]2O[C@H](CO)[C@@H](O)[C@H]2O)c(=O)[nH]1</smiles>

2

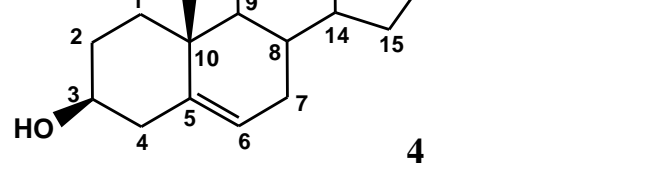

\section{Figure 1. Compounds 1-4.}

\section{Antimicrobial activity of different extracts of Justicia spicigera}

The current study provides an evidence that all extracts of Justicia spicigera showed no activity against Aspergillus flavus and candida albicans while the total extract and dichloromethane extract showed moderate activity against Bacillus subtilis $(11 \mathrm{~mm}$ and $18 \mathrm{~mm})$ respectively in comparison with ciprofloxacin $(24 \mathrm{~mm})$ and the ethyl acetate extract showed moderate activity against staphylococcus aureus (14mm). The ethyl acetate extract was the only one showed remarkable activity against Salmonella typhimurium (16mm) in comparison with Gentamycin $(17 \mathrm{~mm})$ and weak activity against Escherichia coli (16mm) in comparison with Gentamycin (30mm). 
Table 1: Antimicrobial activity of Justicia spicigera extracts (zone of inhibition in mm):

\begin{tabular}{|c|c|c|c|c|c|c|c|}
\hline & Control & $\begin{array}{c}\text { Total } \\
\text { extract }\end{array}$ & $\begin{array}{c}n- \\
\text { hexa } \\
\text { ne }\end{array}$ & $\begin{array}{c}\text { DC } \\
\text { M }\end{array}$ & EtoAc & $\begin{array}{c}n- \\
\text { BUOH }\end{array}$ & $\mathbf{H}_{2} \mathbf{O}$ \\
\hline Fungi & $\begin{array}{l}\text { Ketoconaz } \\
\text { ole }\end{array}$ & & & & & & \\
\hline spergillus flavus & 16 & NA & NA & NA & NA & NA & NA \\
\hline Candida albicans & 20 & NA & NA & NA & NA & NA & NA \\
\hline$\frac{\text { Gram +ve }}{\text { Bacteria }}$ & $\begin{array}{l}\text { Ciproflox } \\
\text { acin }\end{array}$ & & & & & & \\
\hline $\begin{array}{c}\text { Staphylococcus } \\
\text { aureus }\end{array}$ & 24 & NA & NA & NA & 14 & NA & NA \\
\hline Bacillus subtilis & 26 & 11 & NA & 18 & NA & NA & NA \\
\hline$\frac{\text { Gram -ve }}{\text { Bacteria }}$ & $\begin{array}{c}\text { Gentamyc } \\
\text { in }\end{array}$ & & & & & & \\
\hline $\begin{array}{c}\text { Salmonella } \\
\text { typhimurium }\end{array}$ & 17 & NA & NA & NA & 16 & NA & NA \\
\hline Escherichia coli & 30 & NA & NA & NA & 15 & NA & NA \\
\hline
\end{tabular}

$\mathrm{DCM}=$ dicloromethane $n-\mathrm{BUOH}=n$-butanol $\quad$ EtoAc $=$ ethyl acetate $\mathrm{NA}=$ no activity

\section{Antituberculosis activity of different extracts of}

The $n$-butanol extract of Justicia spicigera showed remarkable antibacterial activity against Mycobacterium tuberculosis (TB) with inhibitory percentage $61.48 \%$ in comparison with isoniazid $93.24 \%$ while the ethyl acetate and dichloromethane extracts showed inhibitory percentage $52.31 \%$ and $56.34 \%$ respectively as shown in (Table 2).

\begin{tabular}{|c|c|}
\hline Sample & Inhibitory \% against Mycobacterium tuberculosis \\
\hline Standard (Isoniazid) & $93.24 \pm 2.1$ \\
\hline Total extract & $39.81 \pm 0.72$ \\
\hline$n$-Hexane fraction & $\mathrm{NA}$ \\
\hline DCM fraction & $56.34 \pm 2.1$ \\
\hline EtOAC fraction & $52.31 \pm 0.63$ \\
\hline$n$-BUOH fraction & $61.48 \pm 1.5$ \\
\hline $\mathrm{H}_{2} \mathrm{O}$ fraction & $\mathrm{NA}$ \\
\hline
\end{tabular}

Table 2: Antituberculosis activity of Justicia spicigera extracts: 
DCM=dicloromethane

$n$-BUOH= $n$-butanol

EtoAc $=$ ethyl acetate

$\mathrm{NA}=$ no activity

\section{Cytotoxic activity of different extracts of Justicia spicigera}

The $n$-hexane, ethyl acetate and $n$-butanol extracts showed remarkable cytotoxic activities against Human breast cancer (MCF-7) cell line with $\mathrm{IC}_{50}$ values 26.6, 49.3 and $43.4 \mu \mathrm{g} / \mathrm{ml}$ respectively and Human lung carcinoma (A-549) cell lines with $\mathrm{IC}_{50}$ values $23.7,19.5$ and $30.1 \mu \mathrm{g} / \mathrm{ml}$ respectively whereas weak activities were detected with the dichloromethane extract as shown in (Table 4)

\begin{tabular}{|l|l|l|}
\hline Sample & $\mathbf{I C}_{\mathbf{5 0}} \boldsymbol{\mu g} / \mathbf{m l}(\mathbf{M C F}-\mathbf{7})$ & $\mathbf{I C}_{\mathbf{5 0}} \boldsymbol{\mu g} / \mathbf{m l}(\mathbf{A - 5 4 9})$ \\
\hline Total extract & 271 & 186 \\
\hline$n$-Hexane fraction & 26.6 & 23.7 \\
\hline DCM fraction & 116 & 101 \\
\hline EtOAC fraction & 49.3 & 19.5 \\
\hline$n$-BUOH fraction & 43.4 & 30.1 \\
\hline $\mathrm{H}_{2} \mathrm{O}$ fraction & 77.9 & 220 \\
\hline
\end{tabular}

Table 3: Cytotoxic activity $\left(\mathrm{IC}_{50}\right)$ of Justicia spicigera extracts:

$\mathrm{IC}_{50}$ : the concentration required to cause toxic effect in $50 \%$ of intact cells.

\section{REFERENCES}

Alonso-Castro A. J., Elizabeth O., Dominguez F., Arana-Argáez V., del Carmen Juárez-Vázquez M., Chávez M. and Ortiz-Andrade R.,( 2012) "Antitumor and immunomodulatory effects of Justicia spicigera Schltdl (Acanthaceae)", Journal of ethnopharmacology, 141(3), 888-894.

Awan A.J., Chaudhry B.A., Muhamed S.A., Muhamed U., Umer F., Khuram I., (2014) "Family Acanthaceae and genus Aphelandra: ethnopharmacological and phytochemical review", International Journal of Pharmaceutical Science, 6(10), 44-55.

Baqueiro-Peña I. and José A. G.,(2014) "Uses of Justicia spicigera in medicine and as a source of pigments", Functional Foods in Health and Disease, 4(9), 401414.

Correa G., Vivian G.D., Debora A.M., Jacqueline T., Humberto D.F., Denise C.C., Dorila P., Antonio F.D.A.,(2014) "Anti-inflammatory and antimicrobial activities of steroids and triterpenes isolated from aerial parts of Justicia acuminatissima (Acanthaceae)", International Journal of Pharmacy and Pharmaceutical Sciences, 6(6), 75-81.

Correa G., Antônio F.D.A.,(2012) "Chemical constituents and biological activities of species of Justicia: a review", Revista Brasileira de Farmacognosia, 22(1), 220-238. 
Deng Y., Chuming G., Nianhe X., and Hua P.,(2016) "Acanthaceae, a new Chinese endemic genus segregated from Justicia (Acanthaceae)", Plant Diversity, 38(6), 312-321.

Durkee L.,(1986) "Flora Costaricensis: family 200 Acanthaceae", Fieldiana, Bot, , 18, $1-87$.

Franzblau S. G., Witzig R. S., McLaughlin J. C., Torres P., Madico G., Hernandez A., and Gilman R.H.,(1998) "Rapid, low-technology MIC determination with clinical Mycobacterium tuberculosis isolates by using the microplate Alamar Blue assay", Journal of clinical microbiology, 36(2), 362-366.

Gomez-Verja J.C., Ricardo R., and María I.A.,(2012) "Chemistry and Pharmacology of Selected Asian and American Medicinal Species of Justicia", Bioactive Phytochemicals: Perspectives for Modern Medicine, 1, 400-418.

Herderich M., W. Feser, and P. Schreier,(1992) "Vomifoliol 9-O- $\beta-D$ glucopyranosyl-4-O- $\beta$-D-xylopyranosyl-6-O- $\beta$-D-glucopyranoside: Trisccharide glucoside from apple fruit", Phytochemistry, , 31(3), 895-897.

Hindler J.A., Howard B.J., and Keiser J.F., (1994) "Antimicrobial agents and antimicrobial susceptibility testing", Clinical and Pathogenic Microbiology, 31(3), 895-897.

Huo C.H., Zhao Y.Y., Liang H., and Lin W.H.,(2005) "Studies on chemical constituents in herbs of Acanthus ilicifolius", Journal of Chinese materia medica, 30(10), 763-765.

Luhat L.P., Munkombwe N.M., Cheuka P.M., and Sikanyika H.,(2016) "Phytochemical and Pharmacological Profiles of the Genus Odontonema (Acanthaceae)", British Journal of Pharmaceutical Research, 14(1), 1-7.

Mabberley D.J.,(1993) "The plant-book: a portable dictionary of the higher plants", Cambridge University Press, 581.

Mosmann T.,(1983) "Rapid colorimetric assay for cellular growth and survival: application to proliferation and cytotoxicity assays", Journal of immunological methods, , 65(1-2), 55-63.

Patra, A., Jha S., Murthy P.N., and Manik S.A.,(2010) "Isolation and characterization of stigmast-5-en-3 $\beta$-ol ( $\beta$-sitosterol) from the leaves of Hygrophila spinosa T. Anders". International Journal of Pharmaceutical Sciences Research, 1(2), 95-100.

Pierre L.L., and Moses, (2015) "Isolation and Characterisation of stigmasterol and $\beta$ sitosterol from Odontonema strictum (Acanthaceae)", Journal of Innovations in Pharmaceuticals and Biological Sciences, 2(1), 88-96.

Su C., Qi B., Wang J., Ding N., Wu Y., Shi X.P., and Tu P.F.,(2018) "Megastigmane glycosides from Urena lobata", Fitoterapia, , 127, 123-128.

Wasshausen D.C. and Wood R.I.,(2004) "Acanthaceae of Bolivia", Contributions from the United States National Herbarium, , 49. 
Wen-Kun L., Si-Qiang C., Ming-Guo S., Yong-Ming L., and Mei-Hua Y.,(2012) "Advances on Chemical Compositions and Pharmacological Studies of Justicia", Natural Product Research \& Development, , 24(4), 539-549.

Xu X.B., Tang F., Guo X.F., Wang J., Yao X., Sun J., and Xun H.,(2015) "Isolation, identification and determination of six nucleosides and two amino acids from bamboo shoots of Gramineae Phyllostachys prominens", Tropical Journal of Pharmaceutical Research, , 14(12), 2239-2246.

\section{الملخص العربي}

"التقييم البيولوجي والمواد الفعالة لنبات البستشيا الحمراء المنزرع في مصر"

للسادة الاكاترة

أحمد عثمان ، و ائل محمدي عفيفي ، محمد عبدالرؤف ، لطفي دياب إسماعيل

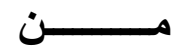

قسم العقاقير - كلية الصيدلة - جامعة الأز هر - القاهرة - مصر.

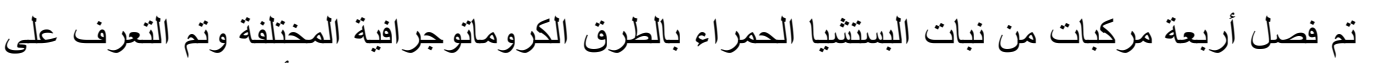

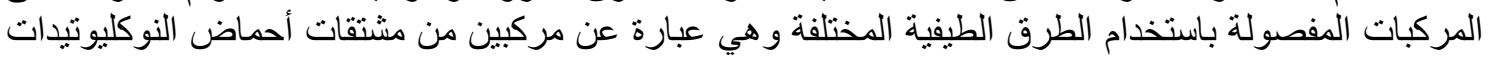

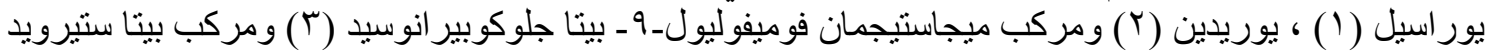

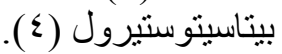

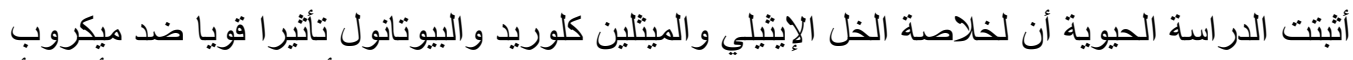

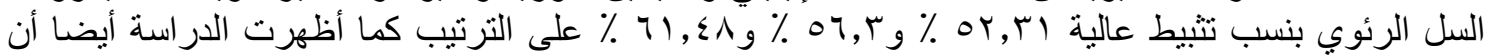

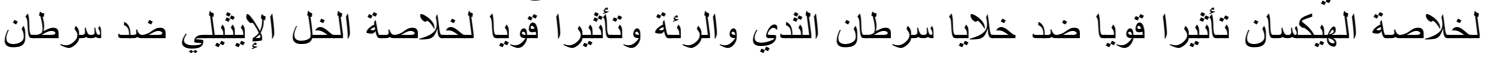

